\title{
ヒト腺様毫胞癌のヌードマウス舌への移植による頸部転移, 肺転移実験モデルの確立
}

\author{
西松成器・梅田正博·島田桂吉
}

\section{Establishment of an experimental model of lymph node and pulmonary metastasis from human adenoid cystic carcinoma by transplantation into the tongue of nude mouse}

\author{
Naruki Nishimatsu $\cdot$ Masahiro UmedA $\cdot$ Keikichi ShImadA
}

\begin{abstract}
Adenoid cystic carcinoma (ACC) is a characteristic malignant tumor that grows very slowly but frequently metastasizes to the lung. To establish a metastasis model of ACC, we transplanted three human orthotopically ACC tissues (KOA-1: solid pattern, KOA-2 : cribriform pattern, and KOA-3: solid pattern) into the tongue of nude mice, and performed histologic examinations after 3 months. The results were as following:

1 ) Each type of ACC was transplantable into the tongue of nude mice, with success rates from $38 \%$ to $67 \%$.

2 ) Histologic patterns of the tranplanted ACC in nude mice were similar to those of specimens obtained from patients during operation.

3 ) Cervical lymph node metastasis was found in the KOA-1 and KOA-2 groups.

4 ) Lung metastasis was found in the KOA-1 and KOA-2 groups.

5 ) This is a new animal model for metastasis from ACC. It is expected to be useful for future studies of metastasis from ACC and its treatment.
\end{abstract}

Key words: adenoid cystic carcinoma (腺様囊胞癌), orthotopic transplantation (同所性移植), metastasis (転移), experimental model (実験モデル)

緒言

転移は癌の最も特徵的な生物学的活性のひとつで, 多数のステップを経て成立する複雑な現象である。こ れまで転移の機序を解明する目的でさまざまな実験モ デルの開発が進められてきたが,一般に実験動物は自 然転移を起こしにくく, 従来は in vivoの転移モデル としては癌細胞を直接脈管内に移植する経脈管移植モ デルが中心であった ${ }^{1)}$. これに対し近年，癌をそれが 発生した臓器と同じ臟器に移植する同所性移植を行う

神戸大学医学部口腔外科学講座

(主任 : 島田桂吉教授)

Department of Maxillofacial Surgery, Kobe University School of Medicine (Chief: Prof. Keikichi Shimada) 受付日：平成10年 2 月 16 日
と転移を生じやすいという報告が成され 2)，以後，い くつかの領域の癌において同所性移植による自然転移 モデルが開発されてきた $\left.{ }^{3}, 4\right)$. 口腔領域においても川 越 ${ }^{5,6)}$, 川尻ら ${ }^{7)}$, Fitch $5^{8)}$, Dinesmen $5^{9)}$ に より同所性移植実験が報告されているが，これらはい ずれも扁平上皮癌 (squamous cell carcinoma：以 下 SCC) が対象であり, 腺様囊胞癌 (adenoid cystic carcinoma：以下 ACC）の in vivo 転移モデルの報 告はこれまでなかった.

ACC は喠液腺原発の悪性腫瘍で, 口腔領域の癌腫 ではSCC に次いで頻度が高いが, 増殖が緩慢な反面, 局所再発や肺転移の頻度が著しく高く, 有効な治療法 は少ないのが現状である10). 今回われわれは, ACC の 転移の機序の解明や治療法開発の基礎となるべく, 転 移モデルの開発を試みることとし，ヒト ACC 組織を 


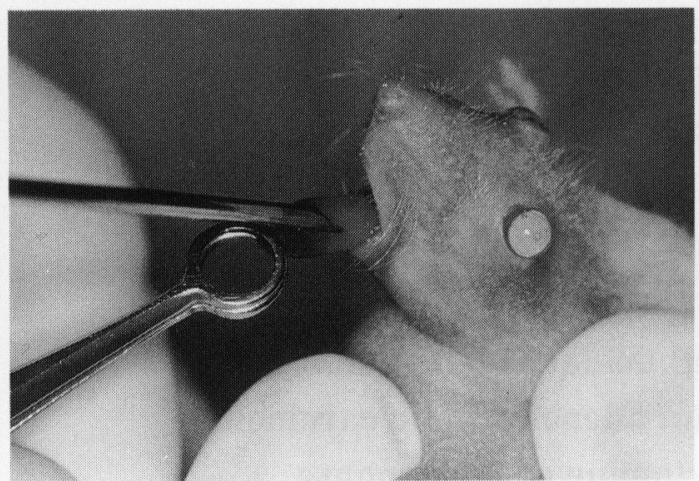

写真 1 腫瘍の移植方法

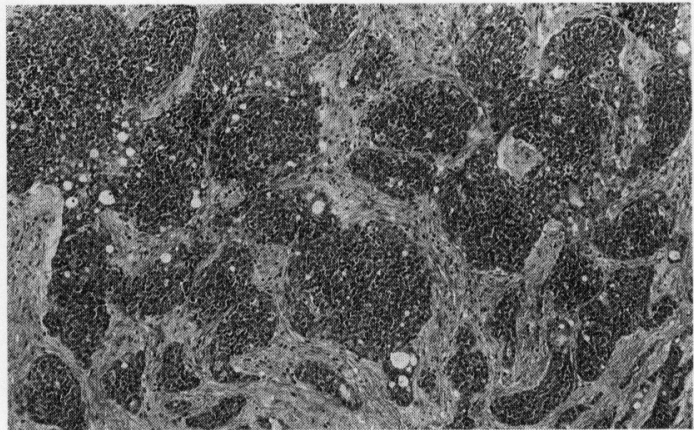

写真 2 KOA-1 (solid pattern 優位) 採取元腫瘍 (HE 染色 $\times 100)$

ヌードマウス舌に移植, 生着や転移について組織学的 に観察したのでその結果を報告する.

\section{研究材料と方法}

移植材料は口蓋, 口底, および上顎洞の小唾液腺原 発の ACC 患者の原発巣切除時に採取した腫瘍組織で, それぞれ KOA-1，KOA-2, KOA-3 と名づけた. 採 取した組織片をただちに直径 $1 \sim 3 \mathrm{~mm}$ に細切, RPMI 1640にて洗浄し, 移植針を用いて日本チャール ズリバー社製 BALB／cANCrj-nu／nu ヌードマウス 背部皮下に移植した。 3 か月後に皮下に生着した腫瘍 を摘出し同様に細切, 移植針につめヌードマウス舌中 央部に移植した（写真 1 ). KOA-1 は26匹（以下 KOA-1 群), KOA- 2 は 5 匹 (以下 KOA- 2 群), KOA3 は 3 匹 (以下 KOA- 3 群) のヌードマウス舌に移植 したが, KOA-1 群の個体が多くなったのは KOA-1 は皮下で大きく増殖したため組織量が多量に採取でき たためである. 舌移植 3 か月後に屠殺し, 舌, 頸部リ

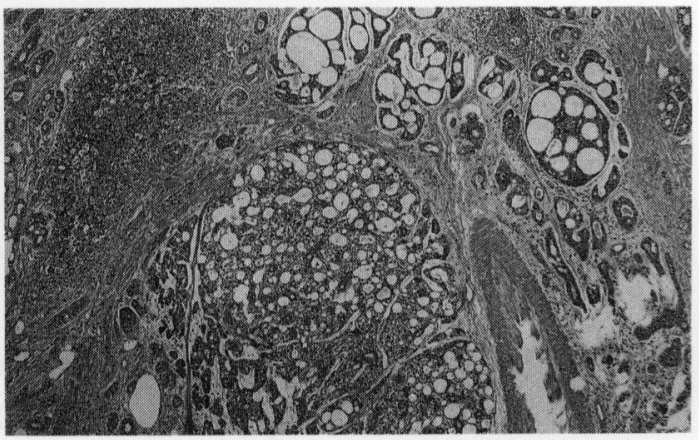

写真 3 KOA- 2 (cribriform pattern 優位) 採取 元腫瘍 $(H E$ 染色 $\times 40)$

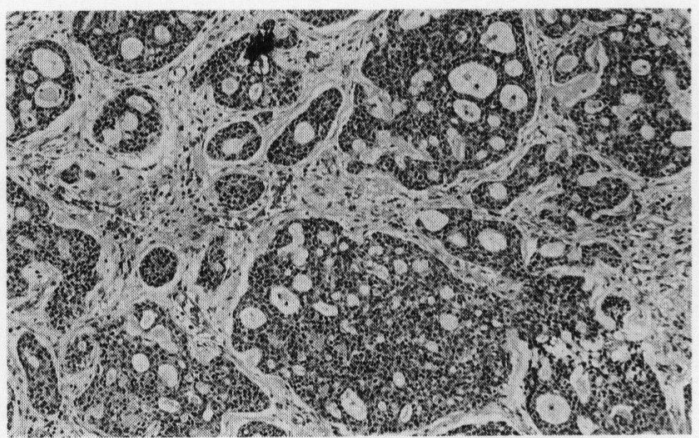

写真 4 KOA-3 (solid pattern \& cribriform pattern 混在型 $)$ 採取元腫瘍 $(\mathrm{HE}$ 染色 $\times 100)$

ンパ節, 肺を摘出, ホルマリン固定パラフィン切片と し, HE 染色を施した. 舌は正中を通る矢状面で全割 した.なお，すべての動物実験は「神戸大学医学部動 物実験に関する指針」にしたがって実施した。

結

果

\section{1. 移植材料の組織学的所見}

KOA-1の患者採取腫湯は, 大部分が充実性胞巣か らなる solid pattern 優位の組織像を示し，一部に trabecular patternもみられた. KOA-2 の患者採取 腫瘍は, ほとんど全体が穊状の偽囊胞構造を伴う典型 的な cribriform patternよりなり, solid pattern を 示す部位はみられながった. KOA-3 の患者採取腫瘍 は一部 cribriform patternを含むが大部分は solid pattern を示していた (写真 2〜4).

KOA-1・2・3 腫場組織片をヌードマウス皮下に 移植したところいずれも生着を認めたが, 移植 3 か月 後の時点で KOA-1 は大きく増殖していたのに対し， 
表 $1 \mathrm{ACC}$ 移植の生着率と転移率

\begin{tabular}{lccc}
\hline 移植材料 & 生着率 & 頸部転移率* & 肺転移率* \\
\hline $\mathrm{KOA}-1$ & $10 / 26(38 \%)$ & $2 / 10(20 \%)$ & $1 / 10(10 \%)$ \\
$\mathrm{KOA}-2$ & $2 / 5(40 \%)$ & $2 / 2(100 \%)$ & $1 / 2(50 \%)$ \\
$\mathrm{KOA}-3$ & $2 / 3(67 \%)$ & 0 & 0 \\
\hline
\end{tabular}

* 転移個数 /生着個数

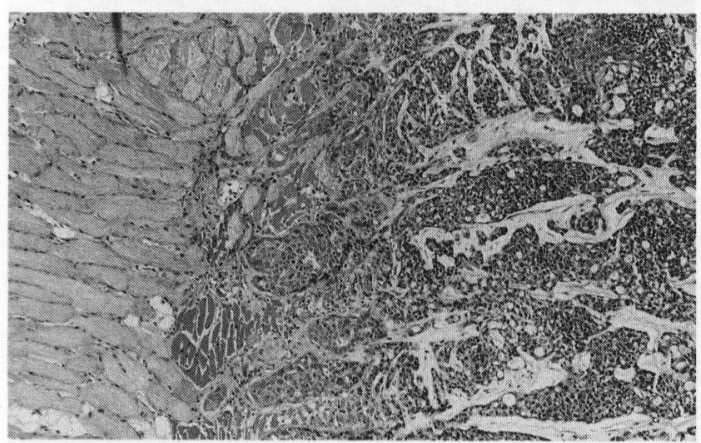

写真 5 KOA- 1 舌生着腫瘍 $(H E$ 染色 $\times 100)$

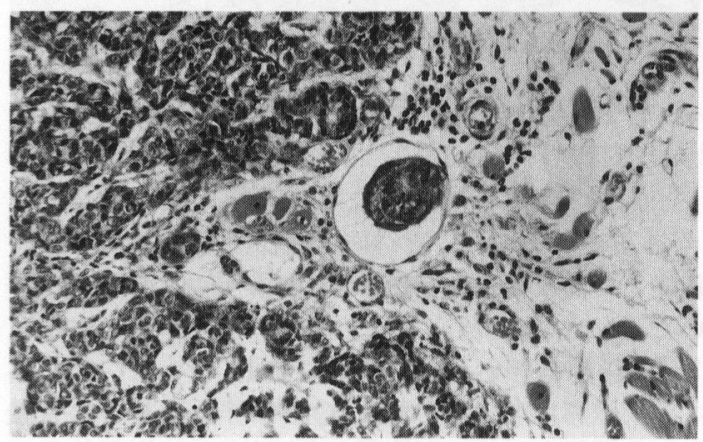

写真 6 KOA- 1 舌脈管浸潤 $(\mathrm{HE}$ 染色 $\times 100)$

KOA- 2 および 3 の増殖は非常に緩慢であった。いず れの腫瘍も周囲組織との境界は明瞭で圧迫性に増殖し ていた. 皮下移植腫瘍の組織像は患者採取腫瘍と類似 しており，KOA-1 では solid pattern, KOA-2では cribriform pattern, KOA-3では solid pattern の 組織像を示した。

2. ヌードマウス舌移植腫瘍の組織学的所見（表 1)

KOA-1 群では26匹のヌードマウス舌に移植され， そのうち10匹 $(38 \%)$ で組織学的に生着が確認された。

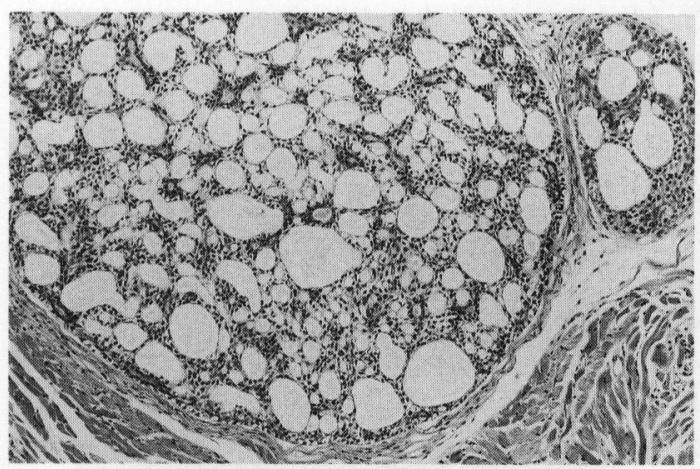

写真 7 KOA- 2 舌生着腫腸 $(\mathrm{HE}$ 染色 $\times 40)$

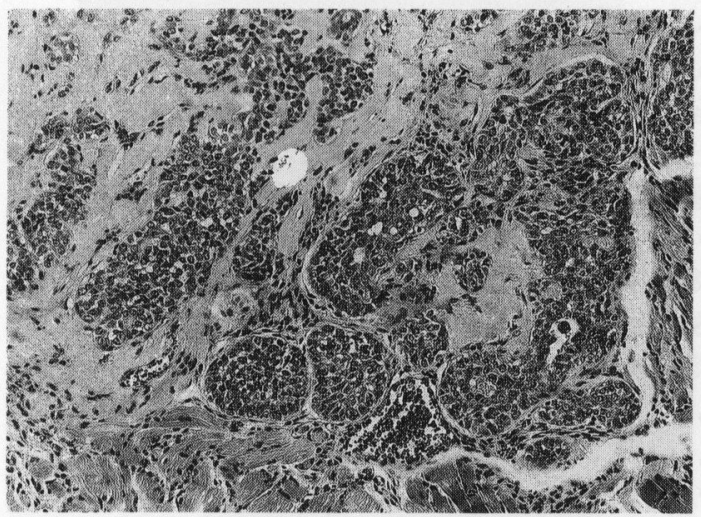

写真 8 KOA- 3 舌生着腫瘍 $(\mathrm{HE}$ 染色 $\times 200)$

移植腫瘍の組織像は皮下移植腫瘍と類似した solid pattern よりなる腫瘍細胞の充実性増殖よりなってい た (写真 5 ). 生着腫瘍の周囲組織との境界はおおむね 明暸であったが, 皮下移植の場合と異なり線維性被膜 は存在せず, 腫瘍細胞は直接舌筋組織と接触, 浸潤し ている所見が認められた。また一部に脈管浸潤がみら れた (写真 6 ).

KOA- 2 群では 5 匹のヌードマウス舌に移植され， そのうち 2 匹 $(40 \%)$ で組織学的に生着か確認された。移 植腫瘍の組織像は皮下移植腫湯と類似した cribriform pattern よりなる腫瘍細胞の胞巣状増殖よりなってい た（写真 7 ). 周囲組織との境界は明らかではなく，舌 筋内に腫瘍胞巣が散在性に認められた。

KOA-3 群では 3 匹のヌードマウス舌に移植され， そのうち 2 匹 $(67 \%)$ で組織学的に生着が確認された。 移植腫瘍の組織像は皮下移植腫瘍と類似した solid pattern よりなる腫瘍の増殖よりなり，一部に多量の 細胞外基質の産生が認められた (写真 8 )。ややはり周囲 


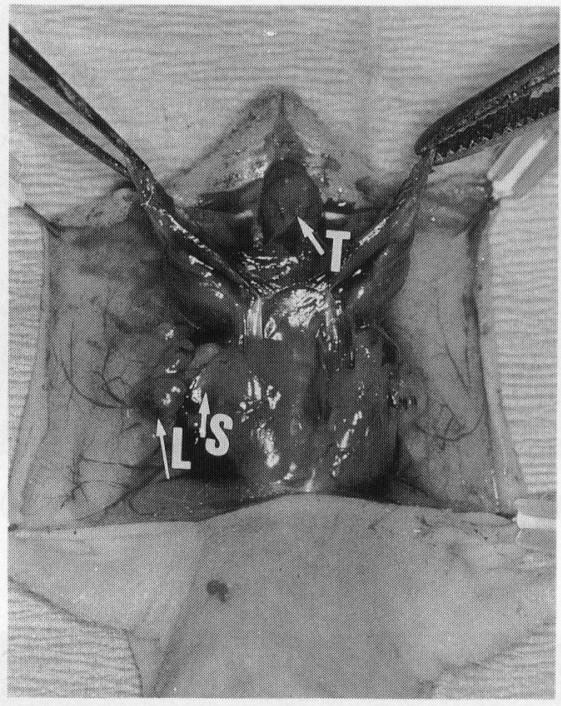

写真 9 頸部リンパ節転移腫瘍肉眼所見 $\mathrm{T}$ : tongue 舌

L : lymph node 須部リンパ節 S : submandibular gland 顎下腺

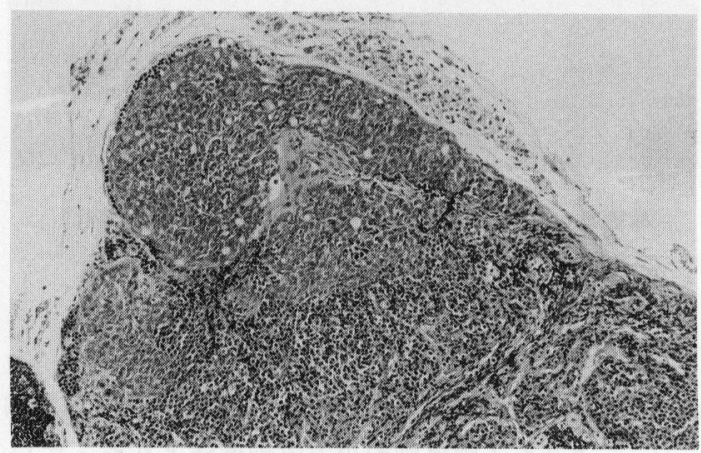

写真10 KOA- 1 頸部リンパ節転移腫瘍 $(\mathrm{HE}$ 染色 $\times 40)$

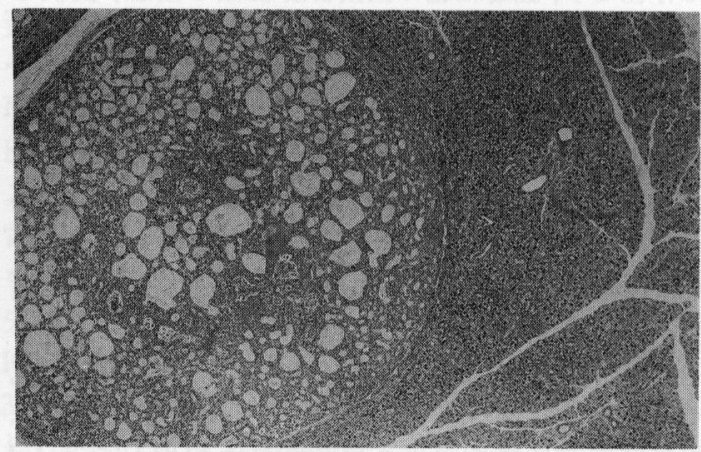

写真11 KOA-2 頸部リンパ節転移腫瘍 (HE 染色 $\times 40)$

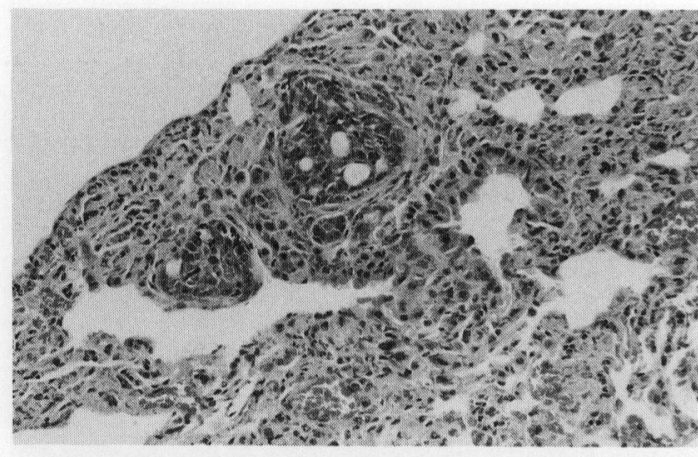

写真12 KOA- 1 肺転移腫瘍 $($ HE 染色 $\times 100)$

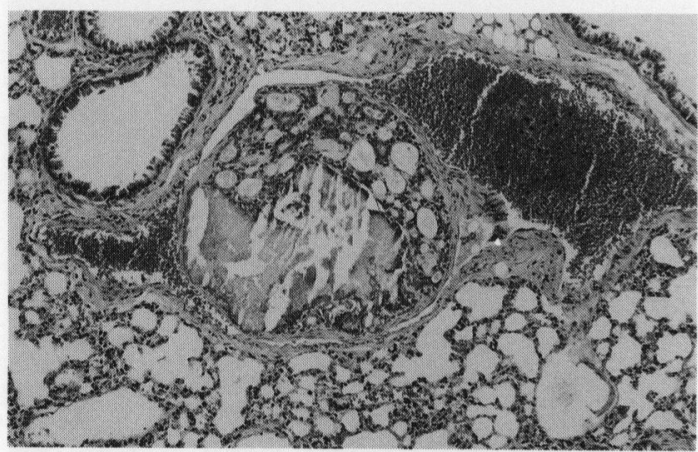

写真13 KOA- 2 肺転移腫瘍 $(H E$ 染色 $\times 100)$

組織との間に被膜は存在せず, 直接舌筋内に浸潤して いた.

\section{3 . 頸部転移および肺転移 (表 1 )}

頸部転移は KOA- 1 群, KOA- 2 群の移植 3 か月後 の動物のそれぞれ 2 匹ずつにみられた. 摘出時肉眼的 所見としては, 舌とは明らかに離れた右側または左側 顎下部に顎下腺と接した形で，単発性のやや腫大した リンパ節様腫瘤としてみられた（写真 9 ). 組織型はい ずれも原発巣腫瘍と非常に類似しており, KOA-1 群 では一部に腺管様構造を伴う solid pattern, KOA-2 群では cribriform patternよりなっていた（写真10, 11).

肺転移は KOA- 1 群, $\mathrm{KOA}-2$ 群の移植 3 か月後の 動物のそれぞれ 1 匹ずつにみられた. 肺摘出時, 肉眼 的には異常は認められなかったが，組織学的には KOA-1 群では一部に腺管様構造を伴う solid pattern, KOA- 2 群では cribriform pattern を示す腫瘍 胞巣の微小転移巣が散見された（写真12,13）. 
考

察

$\mathrm{ACC}$ は唾液腺由来の悪性腫湯で, 発育は緩慢であ るが局所再発や遠隔転移の頻度が著しく高く, 口腔癌 の中でも特徵的な性格を有している゙. ACC の組織型 は,一般には tubular pattern, cribriform pattern, trabecular pattern, solid patternの 4 者に分類され るが,一つの腫瘍内にさまざまな組織型がみられたり， それぞれの移行型がみられたりすることも多い. ACC の組織型と臨床経過との関連性については,これまで 多くの報告がなされてきた11 19). solid patternを含 む症例では予後不良とするものが多く11 17), Szanto らは solid patternの含まれる割合によりACC の組 織型を grade I から grade IIIの 3 段階に分類すること を提唱している ${ }^{10)}$ 。これに対し両者の関連性はないと する報告も少なくなく18,19)，われわれも小唾液腺由来 ACC27例において, 組織型と予後との関連性は認めら れなかったことをすでに報告した99)。このように $\mathrm{ACC}$ の組織型の臨床的意義については不明な点も多 く, 今後さらに検討する必要がある.

ACC の手術では肉眼的に十分な安全域をとって切 除しても組織学的に腫湯細胞の残存を認めることも多 く, 完全切除を行うためには広範囲切除が必要である。 11, 20). しかし腫瘍の組織学的残存があっても予後は決 して悪くはなく, QOL を犠牲にしてまで拡大切除を 行うよりも, 通常の切除に術後照射を併用すればよい との報告も多い12,21)

ACC は肺への血行性転移が多く, 文献的には 17 $67 \%$ の転移率が報告されている ${ }^{9)}$. 当科の 27 例では 5 年で $55 \%, 10$ 年で $79 \%$ の累積肺転移率であった ${ }^{9}$ )。一 方頸部転移は扁平上皮癌に比べてまれとされており， 当科の 27 例では頸部転移は 4 例 $(14.4 \%)$ にみられた のみであった。

以上のように ACC は緩慢な発育, 高い局所浸潤能, 高い血行性転移率という, 非常に特徵的な性格を持っ た悪性腫瘍であるが, その機序については不明な点も 多い.そこで今回われわれは, これら ACC の生物学 的活性の解明に関する基礎的研究や治療法開発の一助 となるべく，臨床像に類似した ACC の転移モデルの 作製を試みた。

癌の転移とは, 局所浸潤, 脈管内侵入, 全身への播 種, 脈管壁への塞栓と離脱, 転移巣での増殖, 免疫機 構からの逸脱など, 多数の複雑な過程を経て成立する ものである. 近年転移に関する研究が盛んになってき たが,これはさまざまな in vitro, in vivoの転移モデ ルの開発によるところが大きい. in vivoで高率に転 移を生じるモデルを作製するためには，樹立細胞株を 実験動物の血管内に移植し，低頻度で生じた転移性の 細胞を再度移植これを繰り返すことにより高転移性細 胞を得る in vivo セレクション法，あるいは in vitro
で細胞をクローニングしたりさまざまな処理を施して 高転移性細胞を得る in vitro セレクション法などが ある ${ }^{1)}$.しかし，これらの転移モデルは転移の微細な 機序の解明には有用であるが, 転移の最も初期の過程 である局所浸潤や脈管内侵入を再現することはできず， 臨床腫湯に類似した転移モデルとしては適当ではない． 癌転移に関係するすべての過程を再現するためには, 癌細胞を動物の皮下などに移植して転移を生じさせる 自然転移モデルが望ましいが，一般にはヌードマウス 移植腫湯は局所浸潤や転移を起こすことはまれとされ てきた. しかし最近では, 癌をそれが発生した臓器と 同じ臓器に移植する，いわゆる同所性移植を行うと， 移植癌でも転移を生じやすいことを明らかにし2，以 後，いくつかの領域において同所性移植による転移モ デルが開発されてきた ${ }^{3,4)}$.

一方, 口腔癌領域においてもいくつかの転移モデル が報告されている.化学発癌モデルとしては以前から DMBA 誘導八ムスター舌癌や煩囊癌があるが, Take らはこの発癌モデルにおけるリンパ節転移についてそ の原発巣の組織学的所見と関連づけて検討し, 臨床腫 瘍と類似したリンパ節転移モデルであると述べてい る ${ }^{22)}$. 同所性移植モデルとしては, 川尻ら 7$)$ が高転移 性の OSC19細胞をヌードマウス口底に移植し, 局所浸 潤やリンパ節転移を生じたと報告した. 川越らは通常 の皮下移植では転移を生じない $\mathrm{HSC}-2,3,4$ 細胞, さらには臨床腫瘍組織片をヌードマウス舌に移植し， 同様に局所浸潤やリンパ節転移を認めたと報告してい $3^{5,6)}$. しかしこれらはいずれも SCC の転移モデル であり，ACC の実験モデルの報告はこれまでなかっ た。

今回われわれが行った研究では, 個体数は少ないも のの, これまでヌードマウス移植や細胞樹立が困難と されてきた ACCにおいても, ヌードマウス舌への移 植によって舌への生着や頸部転移, 肺転移を生じるこ とが明らかにされた。なお KOA-1，KOA- 2 とも現 在ヌードマウス皮下で継代中である.

$\mathrm{ACC}$ の舌への生着率は KOA-1 群で $38 \%, \mathrm{KOA}-2$ 群で40\%, KOA-3 群で $67 \%$ であったが, これらは川越 $ら^{5,6)}$ が報告した SCC の生着率と比べて低いもので あった．また SCC の場合は移植後 1 か月で移植癌は 舌のほほ全体を占拠し，それ以上放置すると動物は攝 食障害のため死亡することがあるのに対し，ACCの 場合は 3 か月後でも腫瘍の増殖はわずかで, 両者の増 殖速度の差が本実験モデルでもよく保持されていた． また組織型についてもその採取元患者の組織型とよく 一致しており，特に，KOA-1，3 は solid pattern 優 位, KOA- 2 は cribriform pattern 優位と互いに異なっ た組織型よりなるため, 両者の生物学的活性を比較検 討するのにも有用と考えられた. 舌筋内での増殖状態 は川越ら 5,6$)$ の SCC の場合と同様, 周囲組織とは被 
膜を介さず,筋組織との直接の接触，浸潤が認められ た。

頸部転移については, 個体数が少なくその頻度につ いては明らかではないが, KOA-1, KOA-2 において 確認できた. ACCの頸部転移は臨床では一般に少な いと考えられている ${ }^{10)}$ が, 実際には不顕性の転移もあ ると思われ，実際の転移様相は不明な点も多い。また 前述のように, 臨床では solid patternを含む腫湯は 頸部転移を生じやすいと考えられるが10), 本実験モデ ルでは個体数が少ないため, 組織型別の検討は不可能 であった. 肺転移についても, 川越らのSCC の実験で は肺転移は報告されていない 5,6$)$ のに対し, KOA-1， KOA-2 の両者で確認され，しかも舌移植腫湟がそれ ほど大きく増大していない時点ですでに多発性の肺転 移を認めているのが特徵的であった。肺転移を生じた 動物は体重減少など肉眼的に特に変化はみられず，摘 出肺の組織学的検索にて初めて診断可能な微小転移で あったが,これは臨床の ACC 患者においても，肺転 移を生じた後も長期間臨床症状なしに生存する場合が 多いことと類似しており，興味深い所見であった。今 後はマウスをさらに長期間生存させた上で, 転移巣腫 湯の変化などについても検討を行いたい.

以上のように, 本実験モデルは前述の ACC の臨床 像と類似した所見を示すことが明らかになった. 今後, 細胞外基質産生や接着分子の発現からみた転移機序の 解明 ${ }^{23)}$ や, 転移予防のための治療法の開発など，本実 験モデルを用いて ACC に関するさまざまな研究に取 り組む予定である。

\section{結語}

ACC の転移モデルの確立を目的として 3 種類のヒ 卜 ACC 組織 (KOA-1 - 3 : solid pattern 優位, KOA- 2 : cribriform pattern 優位)をヌードマウス 舌へ移植し，3か月後に組織学的に観察したところ， 以下の結果を得た.

1. いずれの ACC とも舌への生着がみられ, 生着 率は KOA-1 : 10/26 (38\%), KOA-2：2/5 (40\%), KOA-3 : 2/3（67\%）であった.

2. ヌードマウス移植腫場の組織像は患者採取摘出 物組織像と類似していた。

3. KOA-1 群と KOA- 2 群のそれぞれ 2 匹に頸部 リンパ節転移が認められた。

4. KOA- 1 群と KOA- 2 群のそれぞれ 1 匹に肺転 移が認められた。

5. 本実験モデルは新しいACC の動物転移モデル であり, 今後 ACC の転移やその治療に関する研究に 有用と考えられた。

本論文の一部は第51回日本口腔科学会総会 (1997年 4
月, 新潟）において発表した。

文献

1）矢守隆夫：世界における転移モデル動物実験の 総括. 実験医学 12: 1060-1064 1994.

2) Fidler, I.J.: Critical factors in the biology of human cancer metastasis: twentyeighth G.H.A. clowes memorial award lecture. Cancer Res 50: 6130-6138 1990.

3) Nakajima, M. and Chop, A.M.: Tumor invasion and extracellular matrix degradative engymes: regulation of activity byorgan factors. Semin Cancer Biol 2: 1151271991.

4) 渡邊昌彦, 久保田哲朗, 他：七卜癌同所性移植 による転移モデルの作製. 実験医学 12: 106510691994 .

5）川越弘就, 梅田正博, 他 : ヒト口腔癌組織のヌー ドマウス舌への同所性移植による浸潤, リンパ 節転移モデルの作製. 口科誌 44: 563-568 1995.

6）川越弘就, 梅田正博, 他：ヒト口腔扁平上皮癌 細胞および組織片のヌードマウス舌への同所性 移植による浸潤・リンパ節転移に関する実験的 研究. 神大医紀 58: 1-13 1997.

7）川尻秀一, 熊谷茂宏, 他 : 口腔扁平上皮癌の浸 潤と転移の機序に関する実験的研究 第 3 報 : ヌードマウス口腔内移植法の口腔癌転移モデル としての応用. 口科誌 42: 534-540 1993.

8) Fitch, K.A., Somers, K.D., et al.: The development of a head and neck tumor model in the nude mouse. Head Neck Oncol Res 187-190 1998.

9) Dinensmen, A., Haughy, B., et al.: Development of a new in vivo model for head and neck cancer. Otolaryngol Heak Neck Surg 103: 766-774 1990.

10）西松成器, 梅田正博, 他: 小㗭液腺原発腺様囊 胞癌27例の臨床病理学的研究 組織像, 治療法 と予後との関連性について. 口腔腫瘍 9: 81-92 1998.

11）白砂兼光, 川本眞奈美, 他 : 腺様震胞癌の増殖 様式. 日口外誌 36: 2538-2543 1990.

12) Kim, K.H., Sung, M.W., et al.: Adenoid cystic carcinoma of the head and neck. Arch Otolaryngol 120: 721-726 1994.

13) Dal Maso, M. and Lippi, L.: Adenoid cystic carcinoma of the head and neck: A clinical study of 37 cases. Arch Otolaryngol Head Neck-120: 721-726 1985.

14) Szanto, P.A. and Luna, A.M.: Histologic grading of adenoid cystic carcinoma of the salivary glands. Cancer 54: 1062-1069 1984. 
15) Perzin, K.H., Gullance, P., et al.: Adenoid cystic carcinoma arising in salivary glands: A correlation of histologic features and clinical course. Cancer 42: 2652821978.

16) Chomette, G., Auriol, M., et al.: Adenoid cystic carcinomas of minor salivary glands. Analysis of 86 cases. Virchows Arch Pathol Anat 395: 289-301 1982.

17）松田耕策, 手島貞一：頭頸部腺様譱胞癌66例の 臨床病理学的検討一予後因子について一. 日 口外誌 40: 438-453 1994.

18）浅井昌大, 菅澤 正: 当科における腺様囊胞癌 症例の検討. 頭頸部腫瘍 17: 12-15 1990.

19）遠藤壮平, 木田亮紀, 他 : 頭頸部腺様串胞癌 30 症例の検討. 頭頸部腫瘍 16: 48-52 1989.

20) Spiro, R.H., Huvos, A.G., et al.: Adenoid cystic carcinoma of salivary orgin. A clinicapathlogic study of 242 cases. Am J Surg 128: 512-520 1974.

21）熊埜御堂浩, 大野芳裕, 他 : 頭頸部腺様囊胞癌 40症例の臨床的検討. 頭頸部腫瘍 22: 191-196 1996.

22) Take, Y., Umeda, M., et al.: Lymph node metastases in hamster tongue cancer indu ced with 9, 10-dimethyl-1, 2-benzanthracene (DMBA): association between histological findings and the incidence of neck metastases, and the clinical implications for patients with tongue cancer. $\mathrm{Br} \mathrm{J}$ Oral maxillofac Surg (in press).

23) Shirasuna. K., Sato, M., et al.: A neoplastic epithelial duct cell line of human salivary gland origin. Cancer Res 53: 147 1521993. 